\title{
Antimicrobial Activity Studies of Mixed Ligand Metal Complexes of Some Dibasic Acid and Heterocyclic Bases
}

\author{
Md. Belayet Hossain ${ }^{1}$, Md. Nazmul Hassan¹, M. A. Yousuf ${ }^{2}$ and M. A. Salam 3 \\ ${ }^{1}$ Fish Inspection and Quality Control, Department of Fisheries, Khulna, Bangladesh \\ ${ }^{2}$ Department of Chemistry, Khulna University of Engineering \& Technology, Khulna-9203, Bangladesh \\ ${ }^{3}$ Department of Chemistry, University of Dhaka, Bangladesh
}

\begin{abstract}
Mixed ligand transition metal complexes of $\mathrm{Cu}(\mathrm{II}), \mathrm{Co}(\mathrm{III}), \mathrm{Rh}(\mathrm{III})$ and $\mathrm{Pt}(\mathrm{IV})$ ions with dibasic acids viz., diphenic acid and adipic acid as primary ligands and amine bases as secondary ligands have been synthesized. They were characterized by conventional physical and chemical analyses. The antibacterial and antifungal activities have been evaluated for the synthetic ligands. Disc diffusion methods were employed for antimicrobial assays against five pathogenic bacteria and two fungi. The complexes containing 8-hydroxy quinoline as secondary ligand were much more active than the other complexes. In addition, the complex [Rh(DA)(8-HQ) $\left.\left(\mathrm{H}_{2} \mathrm{O}\right)_{2}\right](4)$ showed the highest antibacterial activity against all bacteria tested (where, DA = Diphenic acid, 8-HQ = 8-hydroxyquinoline) and the complex $\left[\mathrm{Pt}(\mathrm{A})_{2}(\mathrm{Q})_{2}\right](3)$ showed the lowest. On the other hand, he highest inhibition of growth occurred by complex $\mathrm{K}[\mathrm{Cu}(\mathrm{DA})(8-$ $\mathrm{HQ})](\mathbf{1})$ against the fungi Botryodiplodia theobromae and the lowest by complex $\left[\mathrm{Rh}(\mathrm{DA})(8-\mathrm{HQ})\left(\mathrm{H}_{2} \mathrm{O}\right)_{2}\right](4)$ against the fungi Colletotrichum gloesparioides.
\end{abstract}

Key words: Biological activity, Diphenic acid, Heterocyclic amine, Mixed ligand complexes

\section{INTRODUCTION}

Over the past few decades much interest has been shown in the mixed ligand complexes of dibasic acids and amine bases considering that most of them are potentially biologically active. ${ }^{1,2}$ The synthesized chemical compounds, which are used for the treatment of infectious diseases, are known as chemotherapeutic agents. Every year thousands of compounds are synthesized to find out potential chemotherapeutic agent to combat pathogenic microorganisms. In this regard, heterocyclic bases have great importance in biological and industrial

Correspondence to: Md. Belayet Hossain

E-mail: bhtchemru@yahoo.com

Dhaka Univ. J. Pharm. Sci. 7(2): 145-148, 2008 (December) fields. Most of them are used as corrosion inhibitors ${ }^{3-}$ ${ }^{5}$ and their complexes with platinum and copper tested as antitumour ${ }^{6}$ and antibacterial ${ }^{7}$ properties. Mixed ligand complexes of some metal ions containing different dibasic acids as malonic acid ${ }^{8}$, maleic acid ${ }^{9}$ and phthalic acid ${ }^{10}$ with some heterocyclic bases have been reported in some of our recent communications. As part of our ongoing work on mixed ligand complexes, we herein report the synthesis and characterization of $\mathrm{Pt}(\mathrm{IV}), \mathrm{Co}(\mathrm{III})$, $\mathrm{Cu}(\mathrm{II})$ and $\mathrm{Rh}(\mathrm{III})$ ions with diphenic acid or adipic acid as primary and heterocyclic bases, viz., quinoline(Q), 8-hydroxyquinoline(8-HQ) as secondary ligands. These compounds were also 
evaluated for their antibacterial and antifungal properties by the disc diffusion method.

\section{MATERIALS AND METHODS}

General Method of Complex Preparation. Chloride or nitrate salts of various metals $(1 \mathrm{mmol})$ $\left(\mathrm{Cu}\left(\mathrm{NO}_{3}\right)_{2} \cdot 3 \mathrm{H}_{2} \mathrm{O}, \mathrm{CoCl}_{3} \cdot 6 \mathrm{H}_{2} \mathrm{O}, \mathrm{Cl}_{6} \mathrm{H}_{2} \mathrm{Pt}\right.$ aq., $\mathrm{RhCl}_{3}$. $\mathrm{H}_{2} \mathrm{O}$ ) were dissolved in absolute ethanol (20-50 mL). The solution was heated if necessary and filtered to obtain a clear solution of the metal salt. Ethanolic solution of dibasic acids were added in the calculated ratio and mixed with constant stirring. If a pseudo precipitate formed, that was collected and dissolved in acetone. Then $25 \mathrm{~mL}$ of an ethanolic solution of amine bases (e.g. 1-2 mmol of Q, 8-HQ) was added to the resulting mixture. At last the solution of the complex (only 1) was prepared in one equivalent of alcoholic potassium hydroxide. If immediate precipitation of the complex did not occur, the volume of the mixture was reduced by heating on a magnetic hot plate with constant stirring and then it was cooled in an ice-bath. The product formed was isolated, washed with a small amount of ethanol and finally dried in a desiccators over anhydrous $\mathrm{CaCl}_{2}$.

Antibacterial and Antifungal test. Five pathogenic bacteria as listed in Table 3 and two fungi viz., Botryodiplodia theobromae and Colletotrichum gloesparioides were collected from the Department of Pharmacy, University of Rajshahi and selected for antimicrobial test. The tests were performed in Plant Pathology Laboratory, Department of Botany, University of Rajshahi. Nutrient agar was used as bacterial growth medium while Potato dextrose Agar was used as for the growth of fungus. The complexes were dissolved separately in dimethyl sulfoxide (DMSO) to get a concentration of 200, 80, 50 and 30 $\mu \mathrm{g} \mathrm{disc}^{-1}$. Then in vitro antimicrobial activity of these complexes was determined by disc diffusion method $^{11}$. The diameter of the zone of inhibition produced by the complexes was compared with standard antibiotic Kanamycin $\left(30 \mu \mathrm{g} \operatorname{disc}^{-1}\right)$ and Fluconazol

\section{RESULTS AND DISCUSSION}

The complexes were characterized by some experimental techniques viz., elemental analysis, melting point, conductance, magnetic measurements (Table 1) and infrared spectroscopy (Table 2). The infrared spectra of the complexes confirmed the coordination of metal ion with ligands. The observed magnetic moment values of $\mathrm{Pt}(\mathrm{IV})$ and $\operatorname{Rh}(\mathrm{III})(3,4)$ indicated that these complexes were diamagnetic. For $\mathrm{Cu}(\mathrm{II})$, and $\mathrm{Co}(\mathrm{III})$ complexes $(1,2)$ the values of magnetic moment were found between 1.73-2.90 BM.

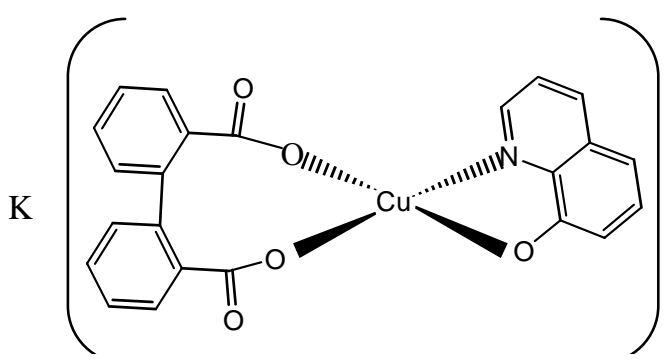

Figure 1. Possible structure of [Cu(DA)(8-HQ)] (1)

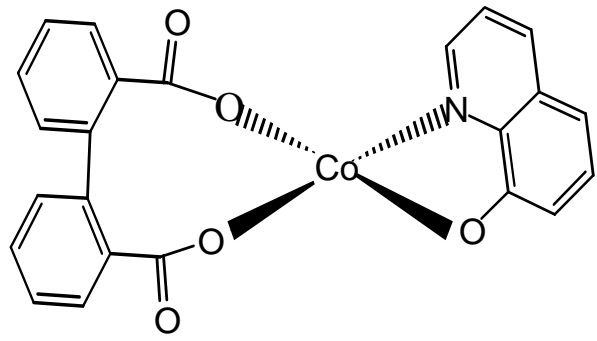

Figure 2. Possible structure of [Co(DA)(8-HQ)] (2)

The antibacterial activity of these complex compounds were studied and results are presented in Table 3. The highest zone of inhibition 30, 28, 34, 28 and $27 \mathrm{~mm}$ were measured for Pseudomonas aeruginosa, Klebsiella spp, Salmonella typhi-A, and Bacillus megaterium respectively in Table 3 . In this experiment, in case of complex no. (2) the lowest inhibition zone was measured as $9 \mathrm{~mm}$ against Pseudomonas aeruginosa. It is revealed from the Table 3 that the complex no. (3) exhibited the highest, while complex no. (2) determined the lowest antibacterial effect. Complex no. (3) showed the 
highest antibacterial activity against all bacteria tested except Pseudomonas aeruginosa.

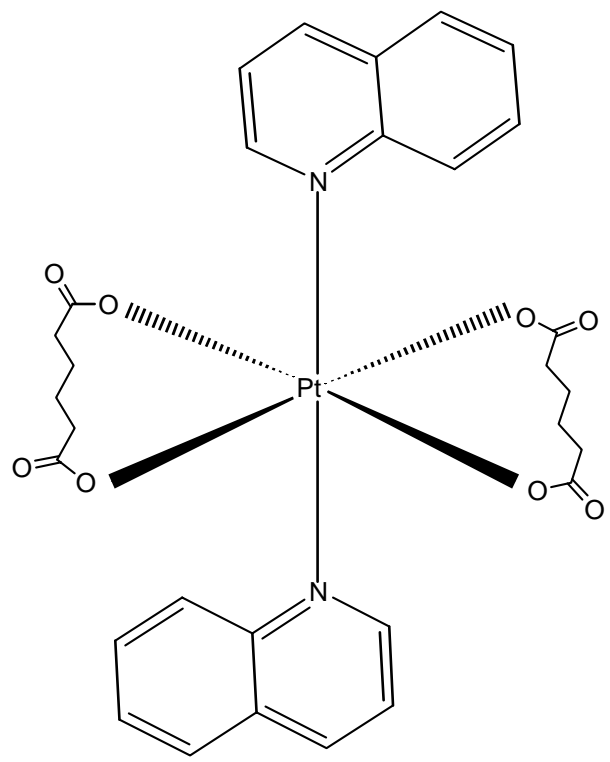

Figure 3. Possible structure of $\left[\mathrm{Pt}(\mathrm{A})_{2}(\mathrm{Q})_{2}\right](3)$
All the metal complexes showed moderate antifungal activity (Table 4) when compared with the standard drug, fluconazol. This is an interesting finding as very few reports have been made on metal complexes as antifungal agents. As different ligands modify the antifungal activity of the complexes the proper ligand selection may reveal metal complexes to be potent antifungal agents. Therefore, the present findings may also open a new search for these complexes for use in fungal diseases.

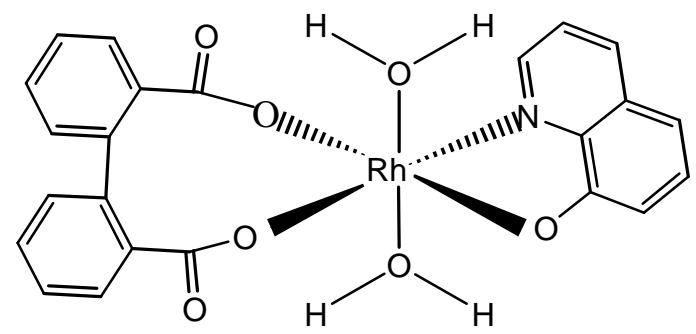

Figure 4. Possible structure of $\left[\mathrm{Rh}(\mathrm{DA})(8-\mathrm{HQ})\left(\mathrm{H}_{2} \mathrm{O}\right)_{2}\right]$ (4)

Table 1. Analytical data and physical properties of the complexes

\begin{tabular}{lllcccc}
\hline $\begin{array}{c}\text { Complex } \\
\text { no. }\end{array}$ & \multicolumn{1}{c}{ Complexes } & Color & Metal (\%) & $\begin{array}{c}\text { M. P or dec. Molar conductance } \\
\text { temp }\left( \pm 5^{\circ}\right)\end{array}$ & $\begin{array}{c}\text { Magnetic } \\
\left(\mathrm{ohm}^{-1} \mathrm{~cm}^{2} \mathrm{~mole}^{-1}\right)\end{array}$ & \begin{tabular}{c} 
Moment (BM) \\
\hline 1
\end{tabular} \\
\hline & $\mathrm{K}[\mathrm{Cu}(\mathrm{DA})(8-\mathrm{HQ})]$ & Brown & $14.18(14.00)$ & 240 & 10.12 & 1.76 \\
3 & {$[\mathrm{Co}(\mathrm{DA})(8-\mathrm{HQ})]$} & Brown & $0.06(10.35)$ & 180 & 15.48 & 2.90 \\
4 & {$\left[\mathrm{Pt}(\mathrm{A})_{2}(\mathrm{Q})_{2}\right]$} & Pale orange & $39.20(39.11)$ & 240 & 11.2 & 0.53 \\
\hline
\end{tabular}

Where $\mathrm{A}=\mathrm{C}_{6} \mathrm{H}_{6} \mathrm{O}_{4}, \mathrm{DA}=\mathrm{C}_{14} \mathrm{H}_{8} \mathrm{O}_{4}, 8-\mathrm{HQ}=\mathrm{C}_{9} \mathrm{H}_{6} \mathrm{NO}, \mathrm{Q}=\mathrm{C}_{9} \mathrm{H}_{7} \mathrm{~N}$, M. $\mathrm{P}=$ Melting Point, $\mathrm{d}=$ decomposition

Table 2. Infrared spectral data of the complexes (band maxima in $\mathrm{cm}^{-1}$ )

\begin{tabular}{ccccccc}
\hline $\begin{array}{c}\text { Com. } \\
\text { No. }\end{array}$ & $v(\mathrm{OH})$ & $v(\mathrm{C}=\mathrm{N})$ & $v(\mathrm{C}=\mathrm{O})$ & $v(\mathrm{C}-\mathrm{O})$ & $v(\mathrm{M}-\mathrm{O})$ & $v(\mathrm{M}-\mathrm{N})$ \\
\hline 1 & - & 1595.0 & 1510.2 & 1377.1 & 467.0 & 441.2 \\
2 & - & 1606.6 & 1489.9 & 1363.6 & 573.6 & 431.2 \\
3 & - & 1609.5 & 1496.7 & 1371.3 & 456.0 & 406.0 \\
4 & 3360.3 & 1597.9 & 1544.9 & 1385.8 & 539.1 & 401.1 \\
\hline
\end{tabular}

*Complexes: Please see Table 1

Table 3. Results of the antibacterial activity of the complexes

\begin{tabular}{lccccc}
\hline \multirow{2}{*}{ Name of Bacteria } & \multicolumn{3}{c}{ Diameter of zone of inhibition (mm) } & \multirow{2}{*}{$\begin{array}{c}\text { Kanamycin } \\
30 \text { mg disc }^{-1}\end{array}$} \\
\cline { 2 - 5 } & 1 & 2 & 3 & 4 & 18 \\
\hline Pseudomonas aeruginosa (-ve) & 30 & 9 & 18 & 22 & 19 \\
Klebsella spp (-ve) & 20 & 10 & 28 & 18 & 26 \\
Salmonella typhi-A (-ve) & 24 & 12 & 34 & 18 & 19 \\
Sarcina lurea (+ve) & 23 & 12 & 28 & 16 & 21 \\
Bacillus megaterium (+ve) & 22 & 11 & 33 & 27 & \\
*Complexes: Please see Table 1 & & & & &
\end{tabular}


Table 4. Antifungal activity of the synthetic complexes (1-4).

\begin{tabular}{ccccccc}
\hline & \multicolumn{2}{c}{ Zone of inhibition of mycelial growth, (mm) } & \multicolumn{2}{c}{ Zone of inhibition of mycelial growth, (mm). } \\
\cline { 2 - 6 } $\begin{array}{c}\text { Complex } \\
\text { no. }\end{array}$ & \multicolumn{3}{c}{ Botryodiplodia theobromae } & \multicolumn{2}{c}{ Colletotrichum gloesparioides } \\
\cline { 2 - 6 } & $80 \mu \mathrm{g} / \mathrm{disc}$ & $50 \mu \mathrm{g} / \mathrm{disc}$ & $30 \mu \mathrm{g} / \mathrm{disc}$ & $80 \mu \mathrm{g} / \mathrm{disc}$ & $50 \mu \mathrm{g} / \mathrm{disc}$ & $30 \mu \mathrm{g} / \mathrm{disc}$ \\
\hline 1 & 15 & 13 & 12 & 12 & 10 & 8 \\
2 & 16 & 13 & 12 & 13 & 11 & 10 \\
3 & 12 & 10 & 8 & 10 & 8 & 8 \\
4 & 11 & 9 & 7 & 6 & -- & -- \\
\hline
\end{tabular}

* Complexes: Please see Table 1

\section{REFERENCES}

1. Zakaria, C. M., Farroque, A., Islam, M. R. and Biswas, M. H. 2000. Antimicrobial screening of ferrocena derivatives of compounds. Oriental J. Chem. 16, 85-90.

2. Part, W. B. and Ruddon, W. 1989. The Anticancer drug, 251254.

3. Talati, J. D. and Gandhi, D. K. 1983. N-heterocyclic compounds as corrosion inhibitors. Corrosion Sci. 23, 13151321.

4. Rysakova, L. V. and Loshkarev, M. A. 1984. Absorption and inhibitor properties of nitrogen containing six membered heterocycles (quinoline) in a neutral medium. Elektrokhimiya 20, 1102-1109.

5. Konno, H., Nagayama, M., Eidheiser, H. L and Granata, R. D. 1984. The composition and properties of a protective layer formed on a steel by anodizing with 8-hydroxyquinoline. Kinzoku-Hyomer Gijutsu 35, 402-408.

6. Doadrio, A. D., Craciunescu, B. S. and Fruma, A. 1979. Relations between the structure and antitumor activity of complex platinate and cuprate salts. An. R. Acad. Farm 45, 497-506.
7. Heinish, L., Fleck, W. F. and Jacob, H. E. 1980. Copper (II) complexes with $\mathrm{N}$-heterocyclic formyl iso thiosemicarbazone withantibactarial and $\beta$-lactamase inhibiting effect. Z.Allg. Mikrobiol. 20, 619.

8. Reza, M. Y., Hossain, M. B. and Islam, M. S. and Alam, S. 2003. Antimicrobial studies of mixed ligand transition metal complexes of malonic acid and heterocyclic bases. Pak. J. Biol. Sci. 6, 1314-1316.

9. Islam, M. S., Hossain, M. B., Reza, Y. M. 2003. Antimicrobial studies of mixed ligand transition metal complexes of maleic acid and heterocyclic amine bases. $J$. Med. Sci. 3, 289-293.

10. Reza, M. Y., Hossain, M. B. and Islam, M. S. 2003. Antimicrobial studies of mixed ligand transition metal complexes of phthalic acid and heterocyclic amine bases. Pak. J. Biol. Sci. 6, 1494 -1496.

11. Bauer, A. W., Kirby, W. M. .M., Shesies, J. C., and Turck, M., 1966. Modified ultrafiltration method fordetg.serum protien binding and its application to penicillins. Am. J. Clin. Pathol. 44, 493-496. 